\title{
Towards Goosepunk: A Contemporary Poetic Treatment of Francis Godwin's The Man in the Moone
}

Abstract

The literary process of thinking ourselves back into the past and then looking forward again through the eyes of our forebears to a possible version of modernity is known as retro-futurism (Guffey and Lemay 434). Its best-known example is the science-fiction subgenre of steampunk, a term invented by the American author K.W. Jeter to describe a mode of fiction which he, together with James P. Blaylock and Tim Powers, began to explore in the 199os (Nicholls and Langford, "Steampunk"). The word is formed on the analogy of cyberpunk, then the latest fashion in science fiction, and implies a form of SF (science fiction) in which the dominant technology is steam. Steampunk looks back nostalgically to the pioneering work of Jules Verne and H.G. Wells, imagining a world simultaneously modern and Victorian. A classic example is The Difference

Interfaces $8 \cdot 2021 \cdot$ pp. 98-112 $\cdot$ DOI 10.54103/interfaces-08-06 
Engine by William Gibson and Bruce Sterling (1990), which depicts the Victorian era as it might have been if Charles Babbage and Ada Lovelace had succeeded in building their prototype computer, leading to the emergence of IT before industrial electric power and the internal combustion engine. Steampunk is a form of alternative history with the emphasis on technology. The -punk suffix of its name derives from cyberpunk, the 1980 os SF genre pioneered by Gibson, Sterling and others, whose portrayal of an often shabby near-future society and emphasis on youth culture and an underworld of criminal hackers suggested parallels with the punk rock movement of a few years earlier (Nicholls, "Cyberpunk;" Roberts 500). Steampunk, despite the involvement of Gibson and Sterling, seems more remote from punk rock, but the suffix had by now become a marker of the new fashion in SF, and was soon attached to other subgenres, some of them at this stage existing mostly as ideas rather than bodies of work. Perhaps surprisingly, it was steampunk rather than cyberpunk which provided the template for these. Its successful combination of history and science fiction has inspired the coinage of clockpunk for a pre-steam SF driven by clockwork (Lake, Mainspring, is a successful example), dieselpunk and atompunk for mid-twentieth-century versions, stonepunk for the Stone Age, while the historian Minsoo Kang has suggested catapunk for a medieval equivalent in which the dominant technology is the catapult siege engine (Kang 246).

Retro-futurist fiction attempts to inhabit the speculations of the historic past, and, of course, those speculations are not pure invention. People in the past did indeed imagine alternative technologies and societies and write down their ideas. This is obvious in the relationship I have already noted between steampunk and the fiction of Verne and Wells, which are often considered, together with the work of Mary Shelley and Edgar Allan Poe, as the first science fiction (Roberts 19). But there was speculative fiction before the nineteenth century, and writers interested in developing the possibilities of the other -punk genres, would do well to explore it. The term proto-science-fiction is sometimes used for this literary genre, and it takes in many of the themes we are accustomed to in later science fiction. The theme of the voyage to the moon, which is to be the focus of this essay, was explored as long ago as the second century CE by the Greek author Lucian in A True History, which describes how the narrator's ship is struck by a violent whirlwind, which causes it to be carried to a remote shining land that turns out to be the moon (Lucian). Lucian's treatment is essentially satirical rather than speculative, lampooning the fantastic voyage narratives of other ancient authors by 
carrying them to absurd lengths; for him, the voyage to the moon is attractive, not as a possibility, but as an impossibility (Roberts 34). While writers in post-classical times continued to speculate about the cosmos, science fiction as a genre 'fell into abeyance' until the mid-seventeenth-century, when the New Astronomy of Galileo, Copernicus and others opened up a very different view of the moon, and initiated a flurry of proto-science-fiction texts (Roberts 34). Three of them were Johannes Kepler's Somnium (first published in 1634), John Wilkins's The Discovery of a World in the Moone (first published in 1638) and Cyrano de Bergerac's The Other World (first published in 1657). The one I wish to concentrate on here, however, is Francis Godwin's The Man in the Moone (first published in 1638), which I have used as the inspiration for a narrative poem that offers a possible precedent for writers wishing to draw on proto-science-fiction for their own retro-futurist experiments. I shall begin with a description of The Man in the Moone and its author, then discuss my own creative treatment of it, and conclude by sketching out the use that might be made of this and similar texts by contemporary writers.

Francis Godwin (1562-1633) was bishop first of Llandaff in Wales, then of Hereford. As a writer, he was best-known by his contemporaries for his Catalogue of the Bishops of England (1601), which lists all the bishops from the beginning of Christianity in England till his own time. The Man in the Moone was not published till five years after his death, which suggests that he did not set much store by it, or, more probably, considered it the kind of frivolous, perhaps even dangerous, material that could harm his reputation. We do not know for certain exactly when he wrote it, but William Poole demonstrates, using internal evidence, that it must be a product of the last decade of his life, and probably of the year 1628. It is a novella in the Spanish picaresque style, influenced by such works as Lazarillo de Tormes (1554); like Lazarillo, Godwin's protagonist, Domingo Gonsales, is a Spaniard who prospers through a series of adventures by a mixture of intelligence and unscrupulousness (Poole 11-12, 26-28).

There is a slight mismatch between Godwin's picaresque form and his science-fiction theme. While the title makes it clear that the voyage to the moon is his main concern, this merely forms the central episode in a story that takes Gonsales from the Low Countries to China (Hutton). For the purposes of my poem, I put aside these early and late parts of the story, and concentrated on Gonsales's moon voyage as narrated by Godwin, the only part of the narrative containing features modern readers would recognise from their reading of science fiction. 
Gonsales tells us that he fell sick on a voyage back from the East Indies, where he had made himself rich trading in pearls and precious stones. The captain of the ship he was returning on put him ashore on the island of Saint Helena, then uninhabited, with a black servant named Diego to attend him. The Man in the Moone is thus in part a desert-island story, a predecessor of Robinson Crusoe as well as of Verne and Wells, though, as Saint Helena was a known stoppingplace for ships, Gonsales has the advantage of a house to live in. On the island, he discovers a species of bird which he calls gansas, a name derived from the Spanish for a goose, though he refers to them as "a certain kinde of wild Swan."” These fabulous birds, with one foot clawed and one webbed, feeding on fish and other birds as well as the more normal vegetable diet of geese and swans, appear to have been Godwin's own invention. The resourceful Gonsales trains the birds to fly to him when he signals with a white sheet, and to carry burdens, using them to communicate with Diego, who lives in a cave some distance away. Later, he devises a harness to yoke them together so that they can carry a larger burden. By this means he is able to make them carry a lamb (Godwin 74-79).

Gonsales's unusually small size has been repeatedly emphasised in his story, and it now enables him to turn his gansas into a flying machine:

At last after divers tryalls I was surprized with a great longing, to cause myself to be carried in the like sorte. Diego, my Moore was likewise possessed with the same desire, and but that otherwise I loved him well, and had need of his helpe, I should have taken that his ambitious affection in very evill part: for I hold it farre more honour to have been the first flying man, then to bee another Neptune that first adventured to sayle upon the Sea [...] I placed my selfe with all my trinckets, upon the top of a rocke at the Rivers mouth, and putting my selfe [...] upon an Engine [...] I caused Diego to advance his Signall: whereupon my Birds presently arose, 25 in number, and carried me over lustily to the other rocke on the other side, being about a Quarter of a league. (Godwin $79-81)$

While this invention is a necessary pre-condition for the New-Astronomy-inspired lunar expedition, it is itself the latest in a long tradition of literary and mythic flying machines, from Daedalus on- 
wards. A manuscript from the fourteenth century shows Alexander the Great in a flying machine powered by griffins (London, British Library, Royal 20 B. xx, f. $76 \mathrm{v}$ ).

Gonsales is not exactly marooned on his island, since he knows he will be able to leave when the next ship arrives; he has invented his flying machine, not to escape but from a mixture of curiosity and the desire for fame and glory. A small fleet eventually puts into the harbour, and he embarks with his contraption, swearing the captain to secrecy about its purpose. However, the fleet is attacked by the English, and the ship with Gonsales aboard strikes a rock, off the coast of the Canary Islands. He uses his flying machine to escape, and lands safely on the coast of Tenerife, close to the slope of Pico del Teide, the highest mountain in the Canaries, which, according to Poole's note, was proverbial at the time for its awe-inspiring height (Godwin 82 note). He congratulates himself on having arrived in Spanish territory, but, instead of being welcomed by his fellow-countrymen, he is soon attacked by the indigenous inhabitants, "a Savage kinde of people" who are at "continuall warre" with the Spaniards. As they run down the slope towards him, brandishing "[1] ong Staves, besides other weapons, which because of their distance from mee I might not discern," he takes off again in his machine. His goal is a nearby cliff, but instead the gansas fly him to the inaccessible top of Pico del Teide, whose height he tells us is "in all estimation at least 15 leagues" - or forty-five miles - above sea level (Godwin 81-86).

Even now, his journey is not finished. It is the time of year when the gansas migrate, and they are soon ready to take off again. Godwin, having already probed the limits of knowledge with his speculative account of a flying machine, now explores another theme that baffled his contemporaries: the mystery of bird migration. The idea that some birds might fly to the moon seemed plausible enough at the time, though it is not clear whether the idea was first advanced in Godwin's novel (Godwin 87 note). At any rate, he gives us a convincing account of their journey there. As they fly they are surrounded by "divers kinds of flyes and Birdes, as especially Swallows, and Cuckoes, whereof there were multitudes, as Motes in the sunne." The two species of birds here mentioned are both migrants, whose wintering grounds were then unknown (Godwin 87).

Godwin's account of the journey to the moon is vivid and detailed, drawing on the insights and speculations of the New Astronomy, while enriching it with his own imagination. As Gonsales leaves the zone of Earth's influence, the reins of his machine grow slack, and 
he sees that the birds are no longer flapping their wings. In our terms, they have escaped its gravitational field, but his own explanation is vaguer, suggesting an analogy with magnetism:

I found then by this Experience that which no Philosopher ever dreamed of, to wit, that those things which wee call heavie, do not sinke toward the Center of the Earth, as their naturall place, but as drawen by a secret property of the Globe of the Earth $[. .$.$] in like sort as the Loadstone draweth$ Iron $[. .].[\mathrm{I}] \mathrm{t}$ is not possible to imagine with what swiftnesse and celeritie they were carried, and whether it were upward, downward, or sidelong, all was one (Godwin 88).

Space is depicted as neither cold nor hot, and filled with perpetual daylight. Gonsales feels no hunger or thirst there, and no sensation of wind or motion. From his vantage point, he is able to see the Earth, which, in accordance with the Copernican system, is turning on its axis from west to east. He sees Africa, "a spot like unto a Peare that had a morsell bitten out upon the one side of him," and America as shown on current maps "almost of an Ovall form." The stars are clearly visible, but do not shine as they do in our night sky because of the daylight background: "of a whitish Colour, like that of the Moone in the daytime" (Godwin 92-93). The only feature of this intensely imaginative description that evokes an older universe of supernatural forces rather than the new one of science is the plague of devils that inhabit this liminal space and pester Gonsales with temptations in many languages:

An other thinge there was exceeding, and more then exceeding, troublesome unto mee, and that was the Illusions of Devills and wicked spirits, who, the first day of my arrivall, came about mee in great numbers, carrying the shapes and likenesse of men and women, wondring at mee like so many Birds about an Owle, and, speaking divers kindes of Languages which I understood not, till at last I light upon them that spake very good Spanish, some Dutch, and othersome Italian (Godwin 88-89).

The devils tempt him with promises to take him back to Spain if he will join their 'fraternity', an offer which he refuses, though he willingly takes the delicious-seeming food and drink they ply him with 
as provisions for his journey, which later turn out, predictably enough, to be fiendish deceptions (Godwin 98-99). It seems that Godwin, like his character, is subject to the pull of conflicting forces: as a scholar, he feels the tug of the New Astronomy, while as a clergyman he still feels compelled to depict the universe in moral and spiritual terms.

As he draws closer to the moon, Gonsales is able to make out its features more clearly:

Then, I perceived also, that it was covered for the most part with a huge and mighty Sea, those parts only being drie Land, which shew unto us somewhat darker than the rest of her body (Godwin 96).

In this, Poole tells us (Godwin 96 note), he contradicts the opinion of Plutarch, who thought that the darker parts of the surface were water - indeed, they are still known as seas or maria - and the lighter parts, land. It is another good example of the acuteness of Godwin's imaginative vision, since it makes perfect sense that any water on the moon would reflect light and thus show up brighter. After a journey of twelve days, the gansas land on a hill on the moon's surface, just as they had taken off from one on Earth. This new world has trees and fauna, as our own does, though because of low gravity, or its pre-Newtonian equivalent, everything is much larger, apart from the migratory birds which have arrived from Earth with the gansas. Seeing that the birds are eating the leaves of a local plant, he tries some himself, and finds them delectable (Godwin 99).

The native Lunarians Godwin now introduces share the gigantism of other features of their world; while their stature varies, it is "for the most part, twice the height of ours." He goes on to discuss their clothing, mostly in negative terms:

For neither did I see any kind of Cloth, Silke, or other stuffe to resemble the matter of that whereof their Clothes were made; neither (which is most strange, of all other) can I devise how to describe the colour of them, being in a manner all clothed alike.

It was neither blacke, nor white, yellow, nor redd, greene nor blew, nor any colour composed of these. (Godwin 99-100) 
Godwin's imagination, so impressive in his account of the lunar passage, is stretched to its limit here. The Lunarians, representing as they do a contrast to humanity, cause language itself to fail. Nevertheless, there is one clear link between their world and our own: God's rule, being universal, must extend here also, and the Lunarians, as rational and, in some respects, ideal beings, acknowledge it. When Gonsales, in his astonishment, crosses himself and calls out "Iesus Maria," the Lunarians fall on their knees and, presumably, pray, "holding up both their hands on high, and repeating all certain words, which I understood not" (Godwin 100).

The next few pages are devoted to an account of the lunar society. The Lunarians are strongly hierarchical: the tallest members have the highest social status and are also the longest-lived, with a lifespan of up to " 30000 Moones, which amounteth unto 1000 Yeares and Upwards." Their prince, called Pylonas, is the tallest of all. They communicate in a language based on musical tones, an idea adapted from European reports of the pitch-based phonetics of Chinese (Godwin 100-09). Their mode of transport is perhaps Godwin's most ingenious invention; they take advantage of the low lunar gravity to propel themselves with fans of feathers. His description is a beautiful example of the combination of accurate and inaccurate speculation that makes his book so appealing:

[T] he Globe of the Moone is not altogether destitute of an attractive Power: but it is so farre weaker than that of the Earth, as if a man do but spring upward with all his force (as Dancers do when they shew their activity by capering) he shall be able to mount 50 or 60 foote high, and then he is beyond all attraction of the Moones Earth, falling down no more, so as by the helpe of these Fans, as with wings, they conveigh themselves in the Ayre in a short space (although not with the swiftnesse that Birds doe) even whither they list. (Godwin 103-04)

One can see Neil Armstrong and his moonwalking colleagues here, but the fans would have been no help to them in the moon's airless environment.

Like Kepler in his Somnium, Godwin speculates about the influence of the length of the lunar day: exposure to the rays of the sun for fourteen days at a time might be too much for the Earthling Gonsales, and for some of the Lunarians themselves (Kepler 20-21). He 
therefore proposes a sort of hibernation, with the main lunar activity taking place in their night-time, illuminated by the reflective light of the Earth, while Gonsales and the weaker Lunarians must sleep for the duration of the fourteen-day lunar night. Recognising that what we call the dark side of the moon (actually the side that is perpetually turned away from the Earth) would not enjoy the benefit of earthlight during the lunar night, Godwin thinks through the implications of this fact, and comes up with a solution that would make life possible there, too:

[T] hey have notwithstandinge a kinde of light (not unlike by their description to our Moon light) which it seemeth the propinquities of the starres and other Planets (so much neerer unto them than us) affordeth. (Godwin 107)

It would seem from his reference to a "second booke" that Godwin planned a sequel in which he would have given us more details of lunar life and described the trip of "20o leagues" that Gonsales made to see Pylonas's liege lord, the king Irdonozur, who talked to him through a window (Godwin 110). We can only guess why he did not complete it. But he abbreviates his account of the seven months residency on the moon and tells how Gonsales returned with his geese, which had already outstayed the normal term of their migration (Godwin 116).

As a creative writer, I have long been interested in both narrative poetry and the adaptation of historic texts. I am not alone in this interest; such books as Seamus Heaney's Beowulf (1999) and interpretations of Homer by Christopher Logue (2001), Simon Armitage (2010) and Alice Oswald (2011) suggest an increasing tendency by poets to re-explore classic texts. This appears to represent a rejection of, or, at least, a counterbalance to, the personal themes of much modern poetry; some poets at any rate are no longer happy to devote their entire oeuvre to dissecting their own experiences and emotions. And mythic and premodern themes, as I argue in the introduction to my version of The Mabinogi (Francis, "Introduction" xii) are arguably better suited to retellings in verse, with its armoury of symbols and metaphors, than the traditionally more literal-minded novel.

My poetry collection Mandeville (2008) is an adaptation of The Travels of Sir John Mandeville, which first appeared in manuscript in the fourteenth century. The original Travels is a work of reference rather than a narrative, describing the world as it appeared from the 
perspective of western Europeans in the Middle Ages. The author tells us he is an English knight and furnishes a few autobiographical details, but these appear to be fictitious, and there is no record of a real Sir John Mandeville in England at the time. His book, which draws heavily on both contemporary and classical sources, combines fairly accurate descriptions of geographical features which would have been known to some of the readers of the time, especially pilgrims to the Holy Land, such as the pyramids and Dead Sea, with legends like the phoenix, and confused attempts to explain realities familiar to us but strange to the narrator and his audience: to Mandeville, bananas are "long apples $[\ldots]$ sweet and delicious to taste," while crocodiles are "a sort of long serpent" (Bale 6, 29, 50, 114). Mandeville has continued to be an inspiration to later works of speculative fiction, from Swift's Gulliver's Travels to C.S. Lewis's The Voyage of the Dawn Treader. Godwin's narrative interested me in the same way as Mandeville's Travels, as an insight into the historical imagination. Looking through the eyes of their narrators, we see facts that have grown familiar to us as they appeared when newly discovered. We eat bananas with our breakfast cereal and watch crocodiles in wildlife documentaries and on YouTube, while the moon has been revealed by modern science and exploration to be devoid of life and rather dull, but through these historical texts we can gain access to a time when the revelation of these things was still fresh and exciting.

In adapting this material, my first problem was the parts of the book before and after the voyage to the moon. I decided simply to cut them, and, since I was writing a first-person narrative like the original, I did this in a dramatic way, making the text into a fragment with the use of ellipses, as if the beginning and end of Gonsales's account had somehow gone missing. The poem opens in mid sentence:

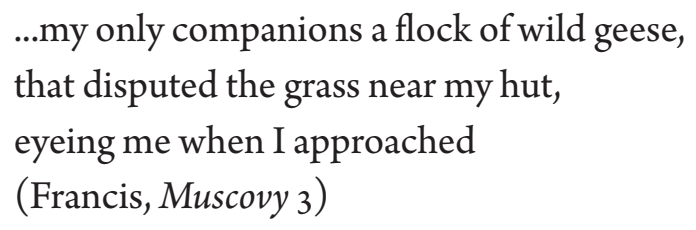

Economy is vital in a poem, so I was concerned to eliminate all unnecessary complications. Instead of the two stays on islands with a sea voyage and battle in between, I implied that Gonsales was a true castaway in the Robinson-Crusoe mould, deprived even of his Man Friday, Diego: this has become such an archetype for us that it needs little explaining, leaving me free to get on with the story. While the 
hero's motivation in the original, in keeping with his character, is fame and glory, here we assume it is escape. Nevertheless, I show Gonsales (who lacks name, nationality and backstory in my version) as something of a dreamer as he contemplates both the moon and his new flock of companions:

The moon rested on the mountain, rock on rock you might step from one to the other.

My geese snored, oval cushions

in the goose-white light.

With much time for thought, I brooded on

that icy noctiluca:

might one live in it?

Had geese reason? What haven

did they fly off to?

(Francis, Muscovy 3 )

The word noctiluca, Latin for nightlight, incidentally, was used by another seventeenth-century thinker, Robert Boyle, for phosphorus. His account of his experiments with this element forms the basis of another of the poems in Muscovy, so the reference here creates a link between the two (Francis, Muscovy 10-11).

The gansas, also, have been simplified in my version: I refer to them as geese, despite the fact that Gonsales (Godwin 77) describes them as swans: I am no longer sure why I made this decision, but it may have been because swans, to British readers, usually suggest the mute swan, which is less associated with migration, whereas V-shaped migrating flocks of geese are a familiar sight in our skies. One difference between prose narrative and poetry is the latter's dependence on metaphor and symbolism, and I found the white geese a fertile source of imagery in this respect: the "goose-white light" of the moon in the quotation above, the "goose-dropping foam" of the waves Gonsales later sees from the mountain-top, the adverb "goose-softly" to describe the experience of alighting from a leap in the low lunar gravity. It is as if the white geese permeate every area of the text (Francis, Muscovy 3, 5, 8).

The second section of my poem describes Gonsales's experiments with his new flying machine, first of all with the lamb, as described in the original: 
I tied him to the frame. The geese flapped.

The rag-doll face showed nothing.

A bleat blew away,

and for the space of two fields

he treadled the air.

(Francis, Muscovy 5 ; cf. Godwin 79)

He now goes on to try the machine himself, interspersing his monologue with muttered Latin prayers:

Myself weighting no more than a dozen lambs,

Sancta Maria, twenty-five geese

(all I have) might, at a stretch

ora pro nobis.

The grass raced between my hanging feet,

tilted and fell. I saw waves

swing past my elbow,

my shadow kicking at them,

in hora mortis.

(Francis, Muscovy 5 )

The third section is central to my poem and faithful to Godwin's original account, which I find the most interesting part of his book. The temperate weather, the perpetual daylight, the "milk and water" dimness of the stars, the migrating swarms of cuckoos and swallows sparkling round about, and the increasingly clear landscape of the moon with its trees, grass and oceans are all included. The only significant omission is that of Godwin's devils, those vestiges of an unscientific world-view that sit so uncomfortably with the more materialist elements of his tale (Godwin 87-98; Francis, Muscovy 6-7).

Because I saw the two flights, the one that stays close to Earth and the one through space, as central to The Man in the Moone, I compressed Godwin's account of the Lunarians and their society to a few lines of the last section of my poem. Like my use of ellipses, this was an exercise in economy. We have grown used to depictions of aliens in the last couple of centuries, and there is nothing much a tyro SF-novelist like Godwin can do to surprise us in this respect. I restricted the description to a few telling details, such as the height of the aliens, and their strange means of locomotion: 
$[\ldots]$ the inhabitants of the place

looked down at me when they came

from heads like rooks' nests.

Each carried two fans of curled feathers

with which to flurry the air

and so leap further.

(Francis, Muscovy 8 )

Godwin makes much of three jewels with magical properties which Pylonas presents to Gonsales. He also mentions that the Lunarians are fond of tobacco (itself then a comparatively new and exotic commodity), and suggests that this links them to the Native Americans, who may be their descendants (Godwin 110-11). All this I compress, borrowing Gonsales's own device of promising to tell the reader in full detail later:

How I was taken before their king and queen, learned the notes of their singing language, tasted moon food, smoked the sweet blue of moon tobacco;

of three gems, a topaz whose yellow could light up a church, a jet whose black scorched the hand

and one of no known colour all this you shall read.

(Francis, Muscovy 9)

In a poem, suggestion is more effective than exhaustive delineation. Mine ends with Gonsales taken away for his fortnight's hibernation. When he wakes, the full experience of lunar life will be made available to him, but the reader can only guess what this will be like:

I woke from my fortnight's sleep, the full moon waiting... (Francis, Muscovy 9)

Part of the pleasure of early science fiction lies in its failures of accurate prediction. Nineteenth-century examples, the kind of texts we 
may consider as providing precedents for the already thriving genre of steampunk, include Poe's Hans Pfall, who travelled to the moon by hot-air balloon, ignoring the difficulty posed by the lack of air, and Verne's use of a giant gun, raising the question of how it would be possible to return. One anthology of early SF epitomises this in the evocative title Astronauts by Gaslight (Tucker et al.). Francis Godwin was writing in an age still very dependent on animals for much of its power, so it is not surprising that he drew on them both for his invention of a flying machine and for space travel. In reading his book we have to imagine our way back to an age when humans and animals lived in closer proximity than they generally do in the West today and when a projected future without their aid was unthinkable. Godwin's proto-science-fiction allows us to glimpse a potential retrofuturist mode, with which, in a very small way, I experimented with in my poem. Perhaps poetry, which requires a less rigorous and detailed approach to the delineation of the material world than the nov$\mathrm{el}$, is the proper place for such experiments, and certainly science fiction poetry is an exciting new genre in its own right (Jones). But the prospect of a fully-fledged fictional subgenre based on proto-sciencefiction is an enticing one. If this should come to pass, I propose, by way of a tribute to Godwin's extraordinary novel, that it should be named goosepunk.

\section{Bibliography}

Guffey, Elizabeth, and Kate C. Lemay. "Retrofuturism and Steampunk." The Oxford Handbook of Science Fiction. Ed. Rob Latham. Oxford: Oxford University Press, 2014. 434-47. Heaney, Seamus. Beowulf: A New Translation. London: Faber and Faber, 1999.

Hutton, Sarah. "The Man in the Moone and the New Astronomy: Godwin, Gilbert, Kepler." Études Épistémè 7 (2005): Web. Updated 1 May 2005, accessed 25 April 2019. Jones, Russell, ed. Where Rockets Burn Through: Contemporary Science Fiction Poems for the UK. London: Penned in the Margins, 2012. 
Kang, Minsoo. “Catapunk: Toward a Medieval Aesthetic of Science Fiction." Medieval Science Fiction, edited by James Paz and Carl Kears. London: King's College Centre for Late Antique and Medieval Studies, 2014. 245-64. Kepler, Johannes. Somnium: The Dream, or Posthumous Work on Lunar Astronomy, translated by Edward Rosen. Mineola: Dover Publications, 2003.

Langford, David. "Steampunk." The Encyclopedia of Science Fiction. Ed. John Clute, David Langford, Peter Nicholls and Graham Sleight. London: Gollancz, (updated 31 August 2018.) Web. Accessed 27 February 2020.

Lake, Jay. Mainspring. New York: Tor Books, 2007.
Logue, Christopher. War Music: an Account of Books 1-4 and 16-19 of Homer's Iliad. London: Faber and Faber, 2001.

Lucian of Samosata. "A True History." Selected Dialogues, edited by C.D.N. Costa. Oxford: Oxford University Press, 2005. 203-33. Nicholls, Peter. "Cyberpunk.” The Encyclopedia of Science Fiction. Ed. John Clute, David Langford, Peter Nicholls and Graham Sleight. London: Gollancz, updated 10 April 2015. Web. Accessed 27 February 2020. Oswald, Alice. Memorial. London: Faber and Faber, 2011.
Poole, William. "Introduction." Francis Godwin. The Man in the Moone. Ed. William Poole. Peterborough: Broadview Editions, 2009. 11-6o.

Roberts, Adam. The History of Science Fiction, Second Edition. London: Palgrave Macmillan, 2016.

Tucker, George, Richard Adams Locke, Edgar Allan Poe, Edward Everett Hale and George Griffith. Astronauts by Gaslight. Edmonton. Black Cat Press, 2006.

Wilkins, John. The Discovery of a World in the Moone. New York: Sagwan Press, 2015. 